\title{
Clinical Results after Surgical Treatment of Spindle Cell Lipomas
}

\author{
İğsi Hücreli Lipomların Cerrahi Tedavisi Sonrası Klinik Sonuçlar
}

\section{Tulay ZENGINKINNET ${ }^{1}$ \\ (D) 0000-0003-3056-2074 \\ Erhan OKAY ${ }^{2}$ \\ (D) 0000-0003-2443-2505 \\ Aykut ÇELİK \\ (i) 0000-0002-5910-0829}

Ayşe Nur TOKSÖZ YILDIRIM

(D) 0000-0003-1708-0003

Muhammed Beșir ÖZTÜRK ${ }^{3}$

(D) 0000-0002-8977-3741

\begin{abstract}
${ }^{1}$ Department of Medical Pathology, Göztepe Prof. Dr. Süleyman Yalçın City Hospital, İstanbul, Turkey

${ }^{2}$ Department of Orthopedics and Traumatology, Göztepe Prof. Dr. Süleyman Yalçın City Hospital, İstanbul, Turkey
\end{abstract}

${ }^{3}$ Department of Plastic, Reconstructive and Aesthetic Surgery, Göztepe Prof. Dr. Süleyman Yalçın City Hospital, İstanbul, Turkey

\section{Corresponding Author Sorumlu Yazar \\ Erhan OKAY \\ erhanokay@yahoo.com}

Received / Geliş Tarihi : 19.06.2021 Accepted / Kabul Tarihi : 01.11.2021 Available Online /

Çevrimiçi Yayın Tarihi : 23.11.2021

\begin{abstract}
Aim: Spindle cell lipoma is a rare tumor. Although located subcutaneously, they are localized in the posterior neck, shoulder, and lumbar regions. It can radiologically mimic liposarcoma. It is important to differentiate spindle cell lipoma from atypical lipomatous tumors. In this study, we aimed to present our studies on our patients with spindle cell lipoma with histopathological and clinical findings and give brief information about the differential diagnosis of this rare lipomatous lesion.

Material and Methods: A total of 29 patients (27 male, 2 female) who underwent surgical treatment for spindle cell lipoma between January 2015 and December 2020 were included in this retrospective study. All patients were presented with mass lesions, and preoperative biopsy was performed in cases with low-fat content mass lesions.

Results: The mean age of the patients was $57.0 \pm 14.6$ (range, 25-79) years and the mean follow-up period was $25.0 \pm 8.6$ (range, $6-47$ ) months. No additional disease was detected in the patients. Marginal resection was preferred in $5(17.2 \%)$ patients with lesions close to neurovascular structures. Wide resection was performed in the other $24(82.8 \%)$ patients. CD34 was positive in all lesions. In one patient, CDK4 was positive, and the diagnosis was made as atypical spindle cell lipoma. At the last follow-up, there was no complication and recurrence in any of the cases.

Conclusion: Spindle cell lipomas should be regarded in the differential diagnosis of lipomatous tumors. Local excision with negative margins may prevent a recurrence. Correct histopathologic differentiation from liposarcoma is of paramount importance for appropriate treatment.
\end{abstract}

Keywords: Spindle; lipoma; upper back; shoulder; neck.

ÖZ

Amaç: İğsi hücreli lipom nadir görülen bir tümördür. Cilt altı yerleşimli olmakla birlikte arka boyun, omuz ve bel bölgesinde de yerleşim göstermektedirler. Radyolojik olarak liposarkomu taklit edebilmektedir. İgssi hücreli lipomanın atipik lipomatöz tümörlerden ayırımı önemlidir. $\mathrm{Bu}$ çalışmada, histopatolojik ve klinik bulguları olan iğsi hücreli lipomlu hastalarımıza ilişkin çalışmalarımızı sunmayı ve bu nadir gözlenen lipomatöz lezyonun ayırıcı tanıları hakkında kısaca bilgi vermeyi amaçladık.

Gereç ve Yöntemler: Bu geriye dönük çalışmaya Ocak 2015 ve Aralık 2020 tarihleri arasında iğsi hücreli lipom nedeniyle cerrahi tedavi uygulanmış olan toplam 29 hasta ( 27 erkek, 2 kadın) dahil edildi. Tüm hastalar kitle lezyonu ile başvurdular ve düşük yağ içerikli kitle lezyonu olan olgularda ameliyat öncesi biyopsi uygulandı.

Bulgular: Hastaların ortalama yaşı 57,0 14,6 (aralık, 25-79) yıl ve ortalama takip süresi ise 25,0 8,6 (aralık, 6-47) ay idi. Hastalarda başka herhangi bir ek hastalık saptanmadı. Nörovasküler yapılara yakın lezyonu olan $5(\% 17,2)$ hastada marjinal rezeksiyon tercih edildi. Diğer $24(\% 82,8)$ hastaya ise geniş rezeksiyon uyguland1. CD34 tüm lezyonlarda pozitifti. Bir hastada CDK4 pozitifti ve bu hastaya atipik iğsi hücreli lipom tanısı konuldu. Son kontrollerinde hiçbir vakada komplikasyon veya nüks saptanmadi.

Sonuç: Lipomatöz tümörlerin ayırıcı tanısında iğsi hücreli lipomlar düşünülmelidir. Negatif sınırlar ile lokal eksizyon nüksü önleyebilir. Uygun tedavi için liposarkomdan doğru histopatolojik ayrım oldukça önemlidir.

Anahtar kelimeler: İğsi; lipom; sırt; omuz; ense. 


\section{INTRODUCTION}

Lipomatous tumors are common lesions of mesenchymal origin. They affect pediatric and adult patients and exhibit a broad spectrum of clinical behavior from benign to malignant. Its prevalence is 2.1 per 1000 people. Most lipomas are located at the subcutaneous tissue and present as a small mass, usually less than $2-3 \mathrm{~cm}$. They can sometimes grow to a larger size and may cause diagnostic challenges. For a lipoma to be referred to as a giant, it should be at least $10 \mathrm{~cm}$ in the axial or coronal dimension or weigh a minimum of $1000 \mathrm{~g}$. These types of lipomas can cause compression to adjacent anatomic structures $(1,2)$.

Spindle cell lipoma, a rare benign lipomatous neoplasm, is a subtype of lipoma composed of mature adipose tissue, ropey collagen, and bland spindle cells (3-5). They usually present as a subcutaneous mass and predilection to localize at the posterior neck, shoulder, and back region. However, sometimes, they can originate from deeper soft tissues and other anatomic localizations. It is important to distinguish spindle cell lipomas from atypical lipomatous tumors, as recurrence rate and dedifferentiation with metastatic potential may occur in atypical lipomatous tumors.

In this study, we aimed to present our patient cohort with spindle cell lipoma with histopathologic and clinical findings and give brief information about the differential diagnoses of this rare entity.

\section{MATERIAL AND METHODS}

Twenty nine cases ( 27 male, 2 female) with spindle cell lipoma were presented to our clinic between January 2015 and December 2020. This study was approved by the clinical research ethics committee of the Istanbul Medeniyet University, Göztepe Training and Research Hospital date: 16.06.2021, number: 0321.

Inclusion criteria included patients with histopathologic diagnosis of spindle cell lipoma in our pathology institution with complete data. Exclusion criteria included patients who underwent biopsy or resection outside of our institution.

Wide or marginal resection was made for all patients. In wide resection, the lesion was resected, leaving $1 \mathrm{~cm}$ of margin with the biopsy tract left with the resection specimen if present. Marginal resection was preferred for lesions with proximity to neurovascular structures. Drain was used postoperatively to avoid hematoma.

\section{Statistical Analysis}

Descriptive statistics were given as mean, standard deviation and minimum-maximum values for numerical variables. Categorical variables were summarized as numbers and percentages.

\section{RESULTS}

A total of 29 patients with spindle cell lipoma were included in the study. Twenty seven $(93.1 \%)$ of the patients were male and the mean age of the patients' was $57.0 \pm 14.6$ (range, $25-79$ ) years. The mean follow-up time was $25.0 \pm 8.6$ (range, 6-47) months.

Anatomic localization was the temporal area in $1(3.5 \%)$ patient, sub-mandibular area in $1(3.5 \%)$ patient, forehead in $3(10.3 \%)$ patients, thigh in $3(10.3 \%)$ patients, neck in $13(44.8 \%)$ patients, shoulder in $1(3.5 \%)$ patient, upper back in $2(6.9 \%)$ patients, hand in $3(10.3 \%)$ patients, arm in $1(3.5 \%)$ patient, and pelvis in $1(3.5 \%)$ patient.

Wide resection was performed in 24 (82.8) patients, and marginal resection was preferred in $5(17.2 \%)$ lesions with close proximity to the neurovascular structures. Otherwise, wide resection was performed.

No recurrence was detected during the patients' follow-up.

Histopathologically, the diagnosis was confirmed with two pathologists experienced in orthopedic oncology cases. Preoperative biopsy was performed for 8 cases with low-fat components detected with magnetic resonance imaging (MRI) to confirm the diagnoses (Figure 1). Wide or marginal resection was performed in all patients. CD34 was positive in all specimens (Figure 2 and 3). CDK4 was positive in one patient (case 2), and the diagnosis was made as atypical spindle cell lipoma.

All the patient's data, including their demographic characteristics and tumoral lesions were given in Table 1 and Table 2 below.

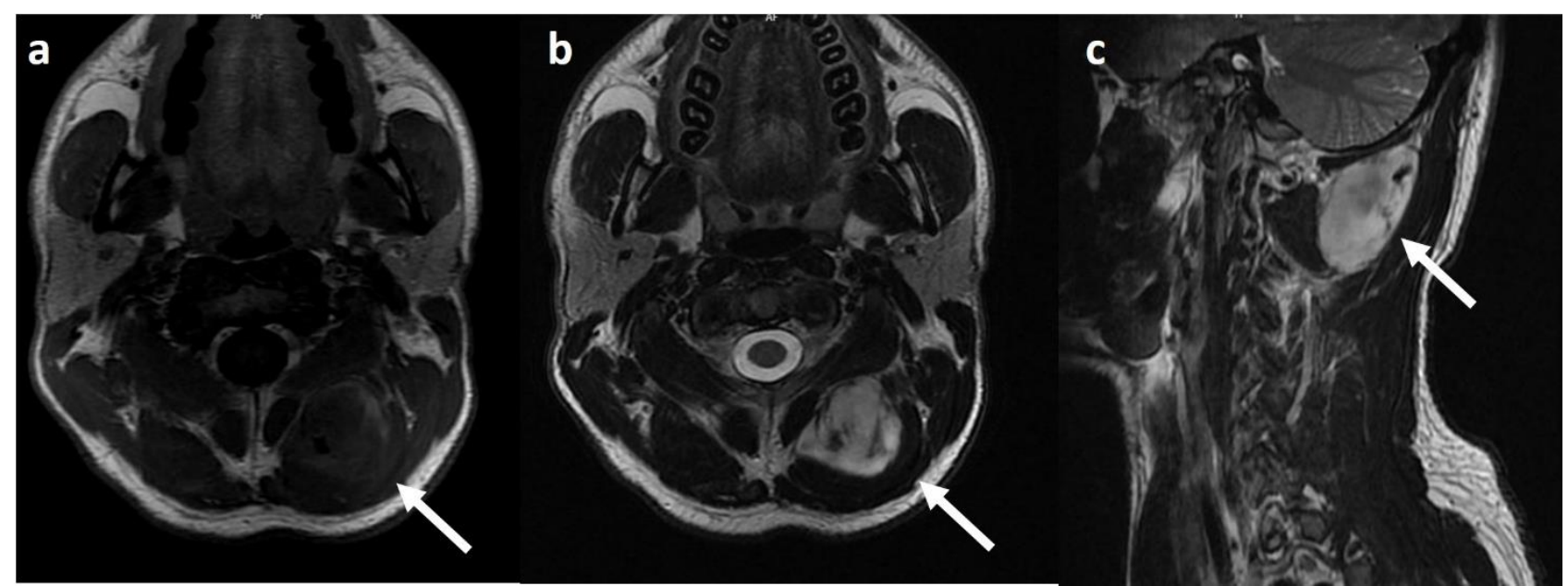

Figure 1. Magnetic resonance imaging view of spindle cell lipoma. T1 axial (a), T2 axial (b), and sagittal view (c) demonstrated well-defined calcific lesions (white arrow) 

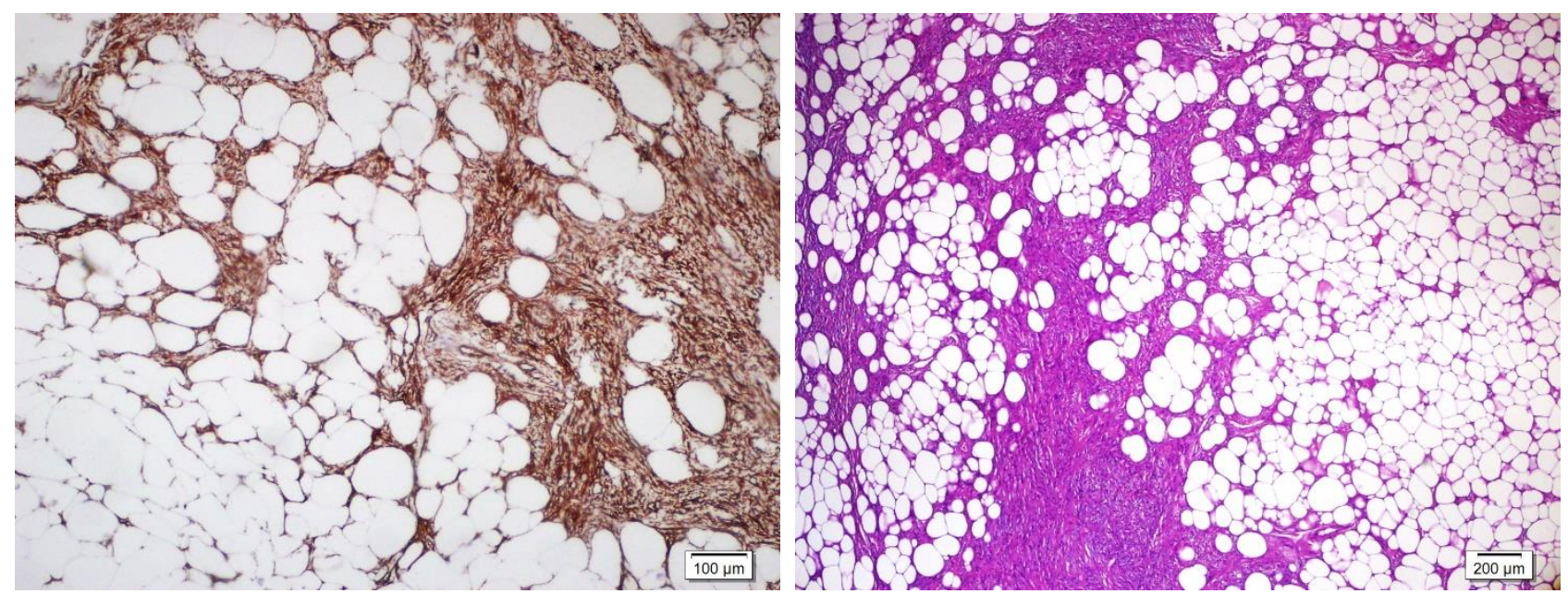

Figure 2. Immunopositivity for CD34 is a consistent feature Figure 3. Spindle cells intermixed with mature adipose tissue of the spindle cell component (immunohistochemistry x200) within a collagenous stroma (Hematoxylin and eosin x100)

Table 1. Clinical data of all patients

\begin{tabular}{|c|c|c|c|c|c|}
\hline Patient & Gender & Age & Follow-up (months) & Localization & Size (cm) \\
\hline 1 & Male & 71 & 24 & Neck & $11 \times 8 \times 6 \mathrm{~cm}$ \\
\hline 2 & Male & 55 & 25 & Thigh & $4 \times 3.5 \times 10.5 \mathrm{~cm}$ \\
\hline 3 & Male & 37 & 20 & Forehead & $0.8 \times 0.5 \times 0.3 \mathrm{~cm}$ \\
\hline 4 & Male & 61 & 20 & Upper back & $4.5 \times 3.5 \times 3 \mathrm{~cm}$ \\
\hline 5 & Male & 73 & 27 & Shoulder & $7 \times 7 \times 3 \mathrm{~cm}$ \\
\hline 6 & Male & 56 & 29 & Neck & $5.5 \times 4 \times 2 \mathrm{~cm}$ \\
\hline 7 & Male & 71 & 47 & Forehead & $1.1 \times 0.6 \times 0.3 \mathrm{~cm}$ \\
\hline 8 & Male & 34 & 15 & Neck & $1.5 \times 1.3 \times 0.5 \mathrm{~cm}$ \\
\hline 9 & Female & 44 & 13 & Hand & $4.6 \times 2.3 \times 2.4 \mathrm{~cm}$ \\
\hline 10 & Male & 63 & 23 & Upper back & $12 \times 8.5 \times 3 \mathrm{~cm}$ \\
\hline 11 & Male & 62 & 28 & Neck & $2.5 \times 1.5 \times 2 \mathrm{~cm}$ \\
\hline 12 & Male & 50 & 6 & Hand & $2 \times 0.5 \times 0.2 \mathrm{~cm}$ \\
\hline 13 & Male & 25 & 25 & Forehead & $1.7 \times 1.3 \times 0.5 \mathrm{~cm}$ \\
\hline 14 & Male & 61 & 20 & Neck & $12 \times 10 \times 4 \mathrm{~cm}$ \\
\hline 15 & Male & 57 & 31 & Neck & $3.5 \times 2.5 \times 1.5 \mathrm{~cm}$ \\
\hline 16 & Male & 61 & 30 & Neck & $3.5 \times 3 \times 2 \mathrm{~cm}$ \\
\hline 17 & Male & 37 & 34 & Temporal area & $3.5 \times 2.5 \times 1.2 \mathrm{~cm}$ \\
\hline 18 & Male & 56 & 39 & Arm & $8 \times 8 \times 2 \mathrm{~cm}$ \\
\hline 19 & Male & 71 & 39 & Thigh & $16 \times 10 \times 2 \mathrm{~cm}$ \\
\hline 20 & Male & 57 & 31 & Neck & $5 \times 5 \times 1.5 \mathrm{~cm}$ \\
\hline 21 & Male & 67 & 24 & Pelvis & $11 \times 9 \times 2.5 \mathrm{~cm}$ \\
\hline 22 & Male & 69 & 20 & Submandibular & $3.5 \times 3 \times 1 \mathrm{~cm}$ \\
\hline 23 & Male & 78 & 21 & Neck & $4.5 \times 4 \times 2 \mathrm{~cm}$ \\
\hline 24 & Male & 66 & 32 & Neck & $5 \times 4 \times 2.5 \mathrm{~cm}$ \\
\hline 25 & Male & 26 & 19 & Neck & $4.5 \times 4.5 \times 2 \mathrm{~cm}$ \\
\hline 26 & Male & 79 & 23 & Neck & $4.3 \times 3 \times 2 \mathrm{~cm}$ \\
\hline 27 & Male & 58 & 26 & Thigh & $2.5 \times 1.5 \times 1.5 \mathrm{~cm}$ \\
\hline 28 & Male & 65 & 21 & Neck & $3 \times 3 \times 2 \mathrm{~cm}$ \\
\hline 29 & Female & 44 & 13 & Hand & $4.6 \times 2.3 \times 2.4 \mathrm{~cm}$ \\
\hline
\end{tabular}

\section{DISCUSSION}

Enzinger and Harvey first coined the term "spindle cell lipoma" in 1975 (6). It is a benign lesion in which spindle cells forms collagen, replacing the mature fat tissue. As they are benign lipomatous lesions, they have never been reported to metastasize. These tumors tend to grow slowly, usually solitary and painless. It is more prevalent in males aged 45 to 65 and are usually treated by local excision.

Subcutaneous tissues of the posterior neck, shoulder or back are commonly localization of spindle cell lipoma. However, the scalp, eyelids, forehead, face, mouth, lower 
Table 2. Patient demographics and clinical progression

\begin{tabular}{lc}
\hline Gender, $\mathrm{n}(\%)$ & $27(93.1)$ \\
$\quad$ Male & $2(6.9)$ \\
Female & $57.0 \pm 14.6(25-79)$ \\
Age (years), mean \pm SD & $25.0 \pm 8.6(6-47)$ \\
Follow-up (months), mean \pm SD & \\
Localization, $\mathrm{n}(\%)$ & $13(44.8)$ \\
$\quad$ Neck & $3(10.3)$ \\
Forehead & $3(10.3)$ \\
Thigh & $1(3.5)$ \\
Shoulder & $2(6.9)$ \\
Upper back & $3(10.3)$ \\
Hand & $1(3.5)$ \\
Pelvis & $1(3.5)$ \\
Submandibular & $1(3.5)$ \\
Temporal & $1(3.5)$ \\
Arm & \\
Surgical treatment, $\mathrm{n}(\%)$ & $24(82.8)$ \\
Wide resection & $5(17.2)$ \\
Marginal resection &
\end{tabular}

SD: standard deviation

jaw, kidney, vulva, and upper and lower extremities are less commonly involved.

In $11(\% 37.9)$ cases of our patient cohort, the lesion was located outside the typical localization. This frequency was similar to Ud Din et al. (7), which reported 57/218 atypical lesions.

Chen et al. (3) reported 40 cases with spindle cell lipoma. There were different morphologies that were difficult to distinguish from atypical lipomas. They observed no recurrence or metastasis at the mean of 2-105 months of follow-up. Jelinek et al. (8) reviewed 27 spindle cell lipomas sized between $2 \mathrm{~cm}$ to $10 \mathrm{~cm}$. He emphasized that the imaging features might differ with minimal fat at MRI or CT compared to conventional lipoma. Imaging might not always be adequate to distinguish these lesions from high-grade sarcoma.

We only had one patient with the diagnosis of atypical spindle cell lipoma in our patient cohort. In microscopy, mild to moderately atypical spindle cells, adipocytes, lipoblasts, pleomorphic cells, multinucleated giant cells within a myxoid, and collagenous matrix are classically observed. It has no predilection for dedifferentiation and metastasis. It is usually encountered in middle-aged males. Weak or focal expression of MDM2 or CDK4 immunoreactivity may be seen as our case displayed CDK4 positivity (9).

Creytens et al. (2) demonstrated a link between atypical spindle cell lipoma and classical spindle cell lipoma. An immunohistochemical and molecular investigation is important for differential diagnosis. Microscopically, the matrix includes collagen fibrils in spindle cell lipomas. In this matrix, mature fat is filled by fibroblast-like spindle cells. Although most spindle cell lipomas are composed of a relatively equal ratio of fat and spindle cells, either component may predominate. Most tumors are composed of spindle cells, string-like collagen fibers and mature adipocytes, surrounded by a fibrous capsule. Scattered mast cells are usually encountered. Spindle cells are often bland, without apparent atypia, pleomorphism, and nuclear mitoses, and are usually arranged in bundles between the collagen fibers.
There are histopathologically different subtypes of spindle cell lipoma: classic form, fibroblastic type, myxoid subtype, Pseudoangiomotus subtype, fat rich type, and low-fat subtype. The cut surface of resected tumoral lesion may be yellow, yellowish-white or greyish-white due to the different fat and collagen ratios. In differential diagnoses, elastofibroma dorsi, solitary fibrous tumors, atypical lipomatous tumors, fibrosarcoma-like lipomatous tumors, mammary-type myofibroblastoma, and spindle cell liposarcoma should be especially taken into consideration. Myxoid subgroups of spindle cell lipoma may resemble myxoid liposarcoma. CDK4 and/or MDM2 immunohistochemical analysis was performed in 12 patients in our patient cohort for differential diagnosis of spindle cell lipoma and atypical lipomatous tumors.

Seo et al. (10) presented a 24-year-old male with spindle cell lipoma in the right supraclavicular area. It was supposed to be a lymphoma variant due to an enlarged lymph node; however, the diagnosis was spindle cell lipoma. At the 6 month follow-up, there was no recurrence. They underlined that in this location, spindle cell lipoma is a possible diagnosis. Mizoshiri et al. (1) reported a 58-year-old Japanese male with a soft tissue mass in his left deltoid muscle. They noted that there had been five other intramuscular spindle cell lipoma cases reported so far in this location.

Fibrosarcoma-like lipomatous neoplasm displays marked cellularity comparable to spindle cell lipoma. They also have lipoblasts with a characteristic lipoblast of an ice cream cone morphology. Deyrup et al. (11) identified fibrosarcoma like lipomatous neoplasm in 12 of 26 suspected cases. They stated that fibrosarcoma-like lipomatous neoplasm must be distinguished from welldifferentiated liposarcoma and myxoid LPS using histologic and molecular features.

There were 6 patients with more than $10 \mathrm{~cm}$ tumoral mass, referred to as giant cell lipomas in our cohort. The tumors can be especially mistaken for liposarcomas. Giant lipomas may also cause a diagnostic challenge and be confused with atypical lipomatous tumors or other liposarcomas. A definitive diagnosis of giant cell lipoma can only be made by histopathological examination. Although very rare, they may also be transformed to liposarcoma (12).

Radiologically, in spindle cell lipomas, the rate of nonlipogenic area was larger than lipogenic areas accompanied by a mixture of mature adipocytes and undifferentiated spindle cells, which is contrary to lipomas as stated by Mizoshiri et al. (1), who described an intramuscular deltoid spindle cell lipoma which reflects these distinct radiological features.

Spindle cell liposarcoma is regarded as another entity. There is hypercellularity, clustered growth, and mild to moderate cytologic atypia, none of which are detected in spindle cell lipoma. Therefore, consultation with a musculoskeletal pathologist is of utmost importance for the general pathologists when in doubt.

\section{CONCLUSION}

Overall, mature adipose tissue, ropey collagen, and bland spindle cells (conventional pattern) are common pathologic features of spindle cell lipoma. Classical localization in adult male may not always be present, 
making the diagnosis difficult. Spindle cell lipoma may sometimes resemble benign and malignant soft tissue tumors; therefore, pathologists, radiologists, orthopedic, and plastic surgeons should be cautious in differential diagnoses and treatment of this rare entity.

Ethics Committee Approval: The study was approved by the Ethics Committee of İstanbul Medeniyet University Göztepe Training and Research Hospital (16.06.2021, 321).

Conflict of Interest: None declared by the authors.

Financial Disclosure: None declared by the authors.

Acknowledgements: None declared by the authors.

Author Contributions: Idea/Concept: TZ, EO, AÇ, ATY, MBO; Design: TZ, EO, AÇ, ATY, MBO; Data Collection/Processing: TZ, EO, AÇ, ATY, MBO; Analysis/Interpretation: TZ, EO, AÇ, ATY, MBO; Literature Review: TZ, EO, AÇ, ATY, MBO; Drafting/Writing: TZ, EO, AÇ, ATY, MBO; Critical Review: TZ, EO, AÇ, ATY, MBO.

\section{REFERENCES}

1. Mizoshiri N, Shirai T, Terauchi R, Arai Y, Fujiwara H, Konishi E, et al. Intramuscular spindle cell lipoma of the deltoid: a case report. J Med Case Rep. 2015;9:38.

2. Creytens D, van Gorp J, Savola S, Ferdinande L, Mentzel T, Libbrecht L. Atypical spindle cell lipoma: a clinicopathologic, immunohistochemical, and molecular study emphasising its relationship to classical spindle cell lipoma. Virchows Arch. 2014;465(1):97-108.

3. Chen S, Huang H, He S, Wang W, Zhao R, Li L, et al.
Spindle cell lipoma: clinicopathologic characterisation of 40 cases. Int J Exp Pathol. 2019;12(7):2613-21.

4. Creytens D. What's new in adipocytic neoplasia? Virchows Arch. 2020;476(1):29-39.

5. Jebastin JAS, Perry KD, Chitale DA, Mott MP, Sanchez J, Fritchie KJ, et al. Atypical lipomatous tumor/well-differentiated liposarcoma with features mimicking spindle cell lipoma. Int J Surg Pathol. 2020;28(3):336-40.

6. Creytens D, Marino-Enriquez A. Atypical spindle cell/pleomorphic lipomatous tumour. In: WHO Classification of Tumours Editorial Board, editors. Soft Tissue and Bone Tumours, WHO Classification of Tumours, 5th edition, volume 3. Lyon, France: IARC Press; 2020. p. 34-5.

7. Ud Din N, Zhang P, Sukov WR, Sattler CA, Jenkins SM, Doyle LA, et al. Spindle cell lipomas arising at atypical locations. Am J Clin Pathol. 2016;146(4):487-95.

8. Jelinek JS, Wu A, Wallace M, Kumar D, Henshaw RM, Murphey MJ, et al. Imaging of spindle cell lipoma. Clin Radiol. 2020;75(5):396.e15-21.

9. Kallen ME, Hornick JL. The 2020 WHO classification: what's new in soft tissue tumor pathology? Am J Surg Pathol. 2021;45(1):e1-23.

10. Seo BF, Kang IS, Oh DY. Spindle cell lipoma: a rare, misunderstood entity. Arch Craniofac Surg. 2014;15(2):102-4.

11. Deyrup AT, Chibon F, Guillou L, Lagarde P, Coindre JM, Weiss SW. Fibrosarcoma-like lipomatous neoplasm: a reappraisal of so-called spindle cell liposarcoma defining a unique lipomatous tumor unrelated to other liposarcomas. Am J Surg Pathol. 2013;37(9):1373-8.

12. Balakrishnan C, Nanavati D, Balakrishnan A, Pane T. Giant lipomas of the upper extremity: Case reports and a literature review. Can J Plast Surg. 2012;20(3):e40-1. 